\title{
Immunohistochemical Analysis of Bcl-2, Bax and Bak Expression in Thyroid Glands from Patients with Graves' Disease
}

\author{
YUJI HIROMATSU, HIROO KAKU, TOKUNORI MUKAI, IKUYO MIYAKE, TOMOKA FUKUTANI, \\ MARI KOGA, SHINGO SHOJI, SHUJI TODA* AND NORIMASA KOIKE** \\ Division of Endocrinology and Metabolism, Department of Medicine, Kurume University School of Medicine, Kurume 830-0011, \\ Japan \\ *Division of Cellular \& Molecular Pathology, Department of Pathology and Biodefense, Faculty of Medicine, Saga University, Saga \\ 849-8501, Japan \\ **Koike Hospital, Saga 840-0862, Japan
}

\begin{abstract}
In order to clarify the role of apoptosis and the expression of Bcl-2 family proteins in the pathology of Graves' disease (GD), we evaluated the apoptosis by in situ end-labeling of fragmented DNA and the expression of Bcl-2, Bax and Bak by immunohistochemistry in thyroid tissues from 20 patients with GD and in normal thyroid tissues from 6 patients with follicular adenoma $(\mathrm{N})$. Apoptotic nuclei were found in thyrocytes and in germinal center of lymphoid follicles. Bcl2 was strongly expressed in both GD and $\mathrm{N}$ thyrocytes. Bax was not expressed in either GD or N thyrocytes. Bak was expressed in thyrocytes from 5 of 20 patients with GD, while it was detected in all $\mathrm{N}$ thyrocytes. In lymphoid follicles Bcl-2 was expressed in the mantle zone, while Bax and Bak were both expressed in the germinal center. The percentage of apoptotic nuclei in GD thyrocytes was low $(0 \sim 3.6 \%)$, and negatively correlated with the weight of the thyroid glands resected ( $\mathrm{rs}=-0.43, P<0.05)$. It was greater in Bak-positive GD thyrocytes than in Bak-negative ones $(\mathrm{mean} \pm \mathrm{SD}$; $1.7 \pm 0.7 \%$ vs. $0.7 \pm 0.9 \%, P<0.05$ ). These findings suggest that the differential expression of Bcl-2 family proteins in both thyrocytes and lymphoid follicles may be involved in the pathology of GD.
\end{abstract}

Key words: Apoptosis, Bcl-2, Bax, Bak, Graves’ disease

(Endocrine Journal 51: 399-405, 2004)

APOPTOSIS is a type of cell death that has been shown to contribute to cell destruction and proliferation [1]. Fas/Fas ligand and Bcl-2 family interactions are important mechanisms to control apoptosis $[1,2]$. The ratio of the expression of death antagonists $(\mathrm{Bcl}-2$, Bcl-XL, Mcl-1) to death agonists (Bax, Bak, Bcl-Xs, $\mathrm{Bad}$ ) determines the survival or death of cells in physiological and pathological conditions such as cancer growth [2-4], neuronal apoptosis following cerebral

Received: November 4, 2003

Accepted: April 26, 2004

Correspondence to: Yuji HIROMATSU, M.D., Division of Endocrinology and Metabolism, Department of Medicine, Kurume University School of Medicine, 67 Asahimachi, Kurume, Fukuoka 830-0011, Japan artery occlusion [5] and regeneration of various cells $[6,7]$. Apoptosis have been recently demonstrated to be involved in the pathogenesis of Hashimoto's thyroiditis [8-15], although the Fas ligand expression in thyrocytes is controversial [12-20]. Graves' disease (GD) is an autoimmune thyroid disorder and hyperplasia of thyroid glands by stimulation with antithyrotropin receptor antibody (TRAb) is a histological hallmark [21, 22]. We have previously reported the increased level of serum soluble Fas in patients with GD [23] and functional expression of Fas ligand in thyrocytes of GD patients [19], and may render thyrocytes resistant to Fas-mediated apoptosis. On the other hand, there are a few studies on the expression of Bcl-2 in GD [9-11, 14, 15, 19], and only one report on Bax expression [24], but no report regarding the expression 
of the other Bcl-2 family proteins.

The aim of the present study was to determine the presence of apoptosis and the expression of Bcl-2, Bax and Bak in thyroid tissues from patients with GD.

\section{Materials and Methods}

\section{Thyroid tissue}

We obtained thyroid specimens from 20 patients with GD (all women, aged 18 to $45 \mathrm{yr}$, mean age: $26 \pm$ $8 \mathrm{yr}$ ). The diagnosis of GD was made by the presence of hyperthyroidism, detection of TRAb in serum and/ or increased ${ }^{123} \mathrm{I}$ uptake ratio. Free $\mathrm{T}_{3}$, free $\mathrm{T}_{4}, \mathrm{TSH}$, and anti-thyrotropin antibody (TRAb) were also determined, as previously reported [23, 25]. Anti-thyroglobulin antibody and anti-microsomal antibody were determined using commercial kits (HTG antibody kit, CIS Bio International, France; Serodia AMC, Fujirebio Inc., Tokyo, respectively). Clinical characteristics of the patients were shown in Table 1. Normal thyroid tissue was also obtained from 6 patients with thyroid adenoma, all women aged 23 to $42 \mathrm{yr}(34 \pm 8 \mathrm{yr})$, and used as control. The study protocol was approved by the institutional review board of the Koike Hospital and informed consent was obtained from all subjects after the explanation of the study.

\section{Detection of apoptosis}

Apoptotic cells were detected by in situ end-labeling of fragmented DNA using assay kits (Apop Tag ${ }^{\mathrm{TM}}$, in situ apoptosis detection kit, peroxidase, Oncor Inc., Gaithersburg, MD) as previously described [26]. The paraffin-embedded tissue sections were deparaffinized by xylene and ethanol. Sections were then treated with proteinase $\mathrm{K}(20 \mu \mathrm{g} / \mathrm{ml})$ for digesting protein in tissue. Digoxigenin-dUTP were added to the 3'-OH ends of DNA by terminated deoxynucleotidyl transferase (TdT). After incubating with anti-digoxigenin antibody conjugated with peroxidase, the sections were stained with

Table 1. Clinical characteristics of patients with Graves' disease and expression of Bax, Bak and Bcl-2 and apoptosis in thyrocytes

\begin{tabular}{|c|c|c|c|c|c|c|c|c|c|c|c|c|c|c|}
\hline \multirow{3}{*}{ Case } & \multirow{3}{*}{$\begin{array}{l}\text { Age } \\
(\mathrm{yr})\end{array}$} & \multirow{3}{*}{ Sex } & \multirow{3}{*}{$\begin{array}{c}\mathrm{FT}_{3} \\
(\mathrm{pg} / \mathrm{mL})\end{array}$} & \multirow{3}{*}{$\begin{array}{c}\mathrm{FT}_{4} \\
(\mathrm{ng} / \mathrm{dL})\end{array}$} & \multirow{3}{*}{$\begin{array}{c}\text { TRAb } \\
(\%)\end{array}$} & \multirow{3}{*}{$\begin{array}{c}\mathrm{TgAb} \\
(\mathrm{U} / \mathrm{ml})\end{array}$} & \multirow{3}{*}{$\mathrm{MicAb}$} & \multirow{3}{*}{$\begin{array}{c}\text { Duration of } \\
\text { medication } \\
\text { (months) }\end{array}$} & \multirow{3}{*}{$\begin{array}{l}\text { Current } \\
\text { treatment }\end{array}$} & \multirow{3}{*}{$\begin{array}{l}\text { Weight of } \\
\text { the resected } \\
\text { thyroid }(\mathrm{g})\end{array}$} & \multicolumn{4}{|c|}{ Thyrocytes } \\
\hline & & & & & & & & & & & & ressio & ${ }^{a}$ of & Apoptosis \\
\hline & & & & & & & & & & & Bax & Bak & Bcl-2 & $(\%)$ \\
\hline 1 & 20 & $\mathrm{~F}$ & 2.4 & 0.3 & 44.9 & 1800 & 102400 & 7 & MMI $30 \mathrm{mg}$ & 30.9 & 0 & 1 & 2 & 2.45 \\
\hline 2 & 29 & $\mathrm{~F}$ & 3.5 & 0.5 & 22.8 & 5.7 & ND & $108^{c}$ & MMI $20 \mathrm{mg}$ & 38.3 & 0 & 0 & 2 & 0.57 \\
\hline 3 & 19 & $\mathrm{~F}$ & 3.7 & 0.8 & 3.5 & 242 & 102400 & 4 & $\beta$-blocker & 33.6 & 0 & 0 & 2 & 0.63 \\
\hline 4 & 36 & $\mathrm{~F}$ & 7.4 & 1.7 & 38.7 & 1800 & $<100$ & 7 & PTU $450 \mathrm{mg}$ & 29.3 & 0 & 1 & 2 & 1.99 \\
\hline 5 & 23 & $\mathrm{~F}$ & 3.9 & 0.8 & 23.2 & 0.9 & $<100$ & 8 & PTU $200 \mathrm{mg}$ & 28.3 & 0 & 0 & 2 & 0.51 \\
\hline 6 & 29 & $\mathrm{~F}$ & 5.5 & 1.5 & 0.5 & 120.9 & 102400 & 1 & PTU $300 \mathrm{mg}$ & 23.1 & 0 & 0 & 2 & 0.51 \\
\hline 7 & 45 & $\mathrm{~F}$ & 4.2 & 0.3 & 77.3 & 232 & 102400 & $8^{c}$ & MMI $15 \mathrm{mg}$ & 21.0 & 0 & 1 & 2 & 1.32 \\
\hline 8 & 16 & $\mathrm{~F}$ & 3.3 & 0.9 & 9.2 & 1.6 & 102400 & 5 & PTU $150 \mathrm{mg}$ & 29.0 & 0 & 1 & 2 & 0.73 \\
\hline 9 & 25 & $\mathrm{~F}$ & 4.6 & 0.9 & 42.9 & 154.9 & 102400 & 2 & PTU $300 \mathrm{mg}$ & 10.5 & 0 & 0 & 2 & 3.60 \\
\hline 10 & 34 & $\mathrm{~F}$ & 5.7 & 1.6 & 45.6 & 25.6 & 102400 & 4 & PTU $450 \mathrm{mg}$ & 10.2 & 0 & 0 & 2 & 1.40 \\
\hline 11 & 26 & M & 6.8 & 2.1 & 25.3 & 1.6 & 6400 & 3 & MMI $20 \mathrm{mg}$ & 34.2 & 0 & 0 & 2 & 0.00 \\
\hline 12 & 37 & M & 4.9 & 1.9 & 68.5 & 0.3 & 6400 & 2 & PTU $600 \mathrm{mg}$ & 58.2 & 0 & 0 & 1 & 0.20 \\
\hline 13 & 26 & $\mathrm{~F}$ & 4.4 & 1.1 & 65.8 & 1.3 & ND & 1 & PTU $150 \mathrm{mg}$ & 11.5 & 0 & 0 & 2 & 1.33 \\
\hline 14 & 22 & $\mathrm{~F}$ & 7.3 & 1.7 & 31.2 & 5.9 & 51200 & 4 & MMI $30 \mathrm{mg}$ & 32.1 & 0 & 0 & 2 & 0.33 \\
\hline 15 & 18 & $\mathrm{~F}$ & 5.1 & 1.5 & 36.5 & 1800 & 102400 & 4 & Lithium $1200 \mathrm{mg}$ & 45.2 & 0 & 0 & 2 & 0.40 \\
\hline 16 & 23 & M & 3.5 & 0.7 & 40 & 301 & 6400 & 1 & PTU $450 \mathrm{mg}$ & 23.7 & 0 & 0 & 2 & 0.66 \\
\hline 17 & 22 & $\mathrm{~F}$ & 3.5 & 1.0 & 17.0 & 750.4 & 102400 & 1 & MMI $30 \mathrm{mg}$ & 18.2 & 0 & 0 & 2 & 0.33 \\
\hline 18 & 19 & M & 2.1 & 0.7 & 70.2 & 11.0 & 102400 & 1 & MMI $30 \mathrm{mg}$ & 52.0 & 0 & 2 & 2 & 1.80 \\
\hline 19 & 29 & $\mathrm{~F}$ & 4.8 & 1.6 & NT & 8.7 & ND & $12^{\mathrm{c}}$ & MMI $30 \mathrm{mg}$ & 38.9 & 0 & 0 & 2 & 0.33 \\
\hline 20 & 18 & $\mathrm{~F}$ & 4.8 & 1.5 & 39.4 & 9.1 & 12800 & 3 & MMI $30 \mathrm{mg}$ & 56.9 & 0 & 0 & 2 & 0.10 \\
\hline
\end{tabular}

$\mathrm{FT}_{3}$ : free $\mathrm{T}_{3}, \mathrm{FT}_{4}$ : free $\mathrm{T}_{4}$, MMI: Methimazole, PTU: Propylthiouracil, TRAb: Anti-thyrotropin receptor antibody TgAb: Anti-thyroglobulin antibody, MicAb: Anti-microsomal antibody, ND: not determined

${ }^{a}$ Expression of Bax, Bak and Bcl-2 was assessed as strong positive (2), positive (1) or negative (0) staining by immunohistochemistry. ${ }^{b}$ Apoptosis was assessed as percentages of apoptotic nuclei of thyrocytes. cindicate the periods after the recurrence of GD. 
diaminobenzidine (DAB) and were counterstained with methyl green. The mean percentage of positive staining of nuclei was calculated after counting positively or negatively stained nuclei of 500 thyrocytes in several fields under light microscope by 2 independent observers.

\section{Immunohistochemistry}

Immunohistochemical staining was performed using mouse monoclonal antibodies against human Bcl-2

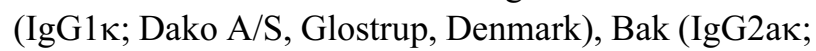
Oncogene Research Products, Cambridge, MA) and

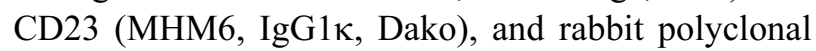
antibody against Bax (IgG; Oncogene), and mouse IgG1 (Dako), mouse IgG2a (Dako) and normal rabbit immunoglobulin (Dako) as negative controls. Positive reactivity was identified using a streptavidin-biotinperoxidase detection system (Dako catalyzed signal amplification system, Dako) as previously reported [26]. Briefly, the paraffin-embedded tissue sections were deparaffinized, and then put in DAKO (R) Target Retrieval Solution (Dako) in order to amplify the signal, and placed in a hot water bath $\left(95-97^{\circ} \mathrm{C}\right)$ for 20 $40 \mathrm{~min}$ and then cooled for $20 \mathrm{~min}$ at room temperature. After blocking endogenous peroxidase activity with a $3 \%$ hydrogen peroxidase solution for $10 \mathrm{~min}$, intrinsic biotin with an Endogenous Avidin/Biotin Blocking kit (Nichirei Corporation, Tokyo Japan), and nonspecific binding by serum-free protein, the tissue was incubated with prediluted mouse monoclonal antibodies $(10 \mu \mathrm{g} / \mathrm{ml})$ or rabbit polyclonal antibodies $(5 \mu \mathrm{g} / \mathrm{ml})$ for $15 \mathrm{~min}$, followed by $15-\mathrm{min}$ incubation with a biotinylated rabbit anti-mouse $\operatorname{IgG}+\mathrm{M}+\mathrm{A}$ antibody or gout anti-rabbit IgG antibody and for 15-min incubation with streptavidin-biotin-peroxidase complex, biotinyl tyramide and hydrogen peroxide, and streptavidin conjugated with peroxidase. Staining was completed with DAB for $5 \mathrm{~min}$, and the specimens were counterstained with Mayer's hematoxylin for 2 to 5 min.

\section{Statistical analysis}

Differences of the expression of Bcl-2 family proteins and percentages of apoptotic cells between groups were evaluated using Mann-Whitney U test, Student's $t$ test or Fisher's exact probability test. Correlations were assessed by Spearman's signed ranks test. A probability level of less than 0.05 was considered significant.

\section{Results}

Apoptotic cells in thyroid tissues

Apoptotic nuclei were observed in thyrocytes (Fig. 1A) and in the germinal center of lymphoid follicles (Fig. 1B). In normal thyroid glands, apoptotic nuclei were rarely found in follicular cells (Fig. 1C). The mean percentage of apoptotic thyrocytes tended to be greater in GD than in N, but the difference was not statistically significant $(1.0 \pm 0.9 \%$ in GD vs. $0.4 \pm 0.3 \%$ in N, Mann-Whitney U test, $P=0.14$ ).

\section{Expression of Bcl-2, Bax and Bak in thyroid tissues}

Bcl-2 was expressed in the cytoplasm of thyrocytes from both GD (Fig. 2A) and N (Fig. 2E). Bak was expressed in all $\mathrm{N}$ thyrocytes (Fig. 2F), while it was not detected in thyrocytes from 15 out of 20 GD patients (Fig. 2B). Bax was not expressed in thyrocytes from either GD (Fig. 2C) or N (Fig. 2G).

In lymphoid follicles, Bcl-2 was expressed in the mantle zone (Fig. 2I), while both Bax and Bak were expressed in the germinal center (Fig. 2J, 2K). CD23positive cells were detected in the germinal center (Fig. 2L).

\section{Relation of apoptosis and Bcl-2 family protein expres- sion in thyroid to the clinical parameters of $G D$}

The percentage of apoptotic cells was negatively correlated with the weight of resected thyroid glands, with free $\mathrm{T}_{4}$ level (Fig. 3). The percentage of apoptotic cells was significantly greater in Bak-positive specimens than Bak-negative specimens $(1.7 \pm 0.7 \%$ vs. $0.7 \pm 0.9 \%$, respectively, Table 2 ). Other clinical parameters including TRAb did not relate with apoptosis or expression of Bcl-2, Bak or Bax of thyrocytes.

\section{Discussion}

We have addressed the involvement of apoptosis and the expression of Bcl-2 family proteins, namely, $\mathrm{Bcl}-2$, Bax and Bak, in thyroid tissue from patients 


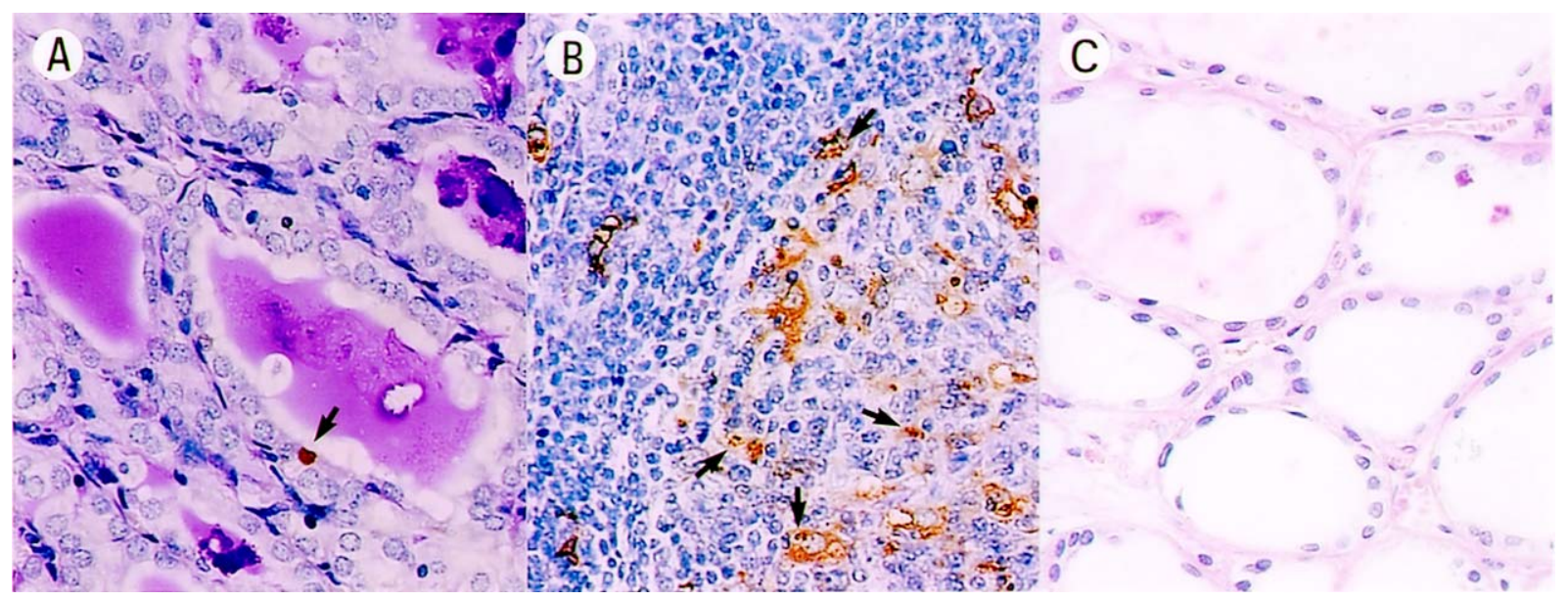

Fig. 1. In situ end-labeling of fragmented DNA in thyroid tissues from patients with GD (A, B) and a control subject (C). Arrows indicate apoptotic nuclei.

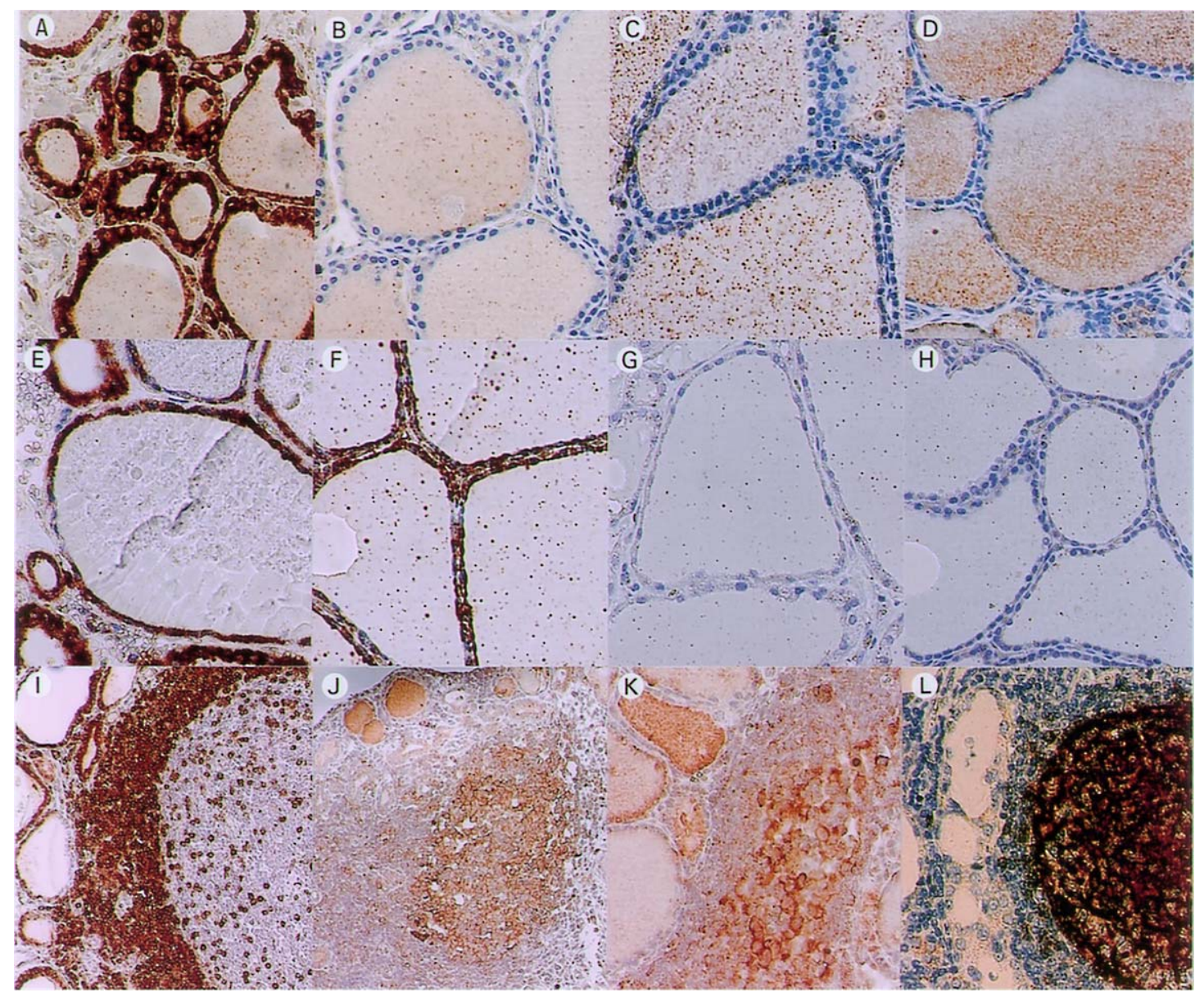

Fig. 2. Immunohistochemical staining with Bcl-2 (A, E, I), Bak (B, F, J), Bax (C, G, K), CD23 (L) and control immunoglobulins (D, mouse IgG2; H, normal rabbit immunoglobulin) in thyroid tissues from patients with GD (A D, I L) and a control subject $(\mathrm{E} \sim \mathrm{H})$. In lymphoid follicles, Bcl-2 protein was detected in the mantle zone, while CD23-positive cells were detected in the germinal center. 

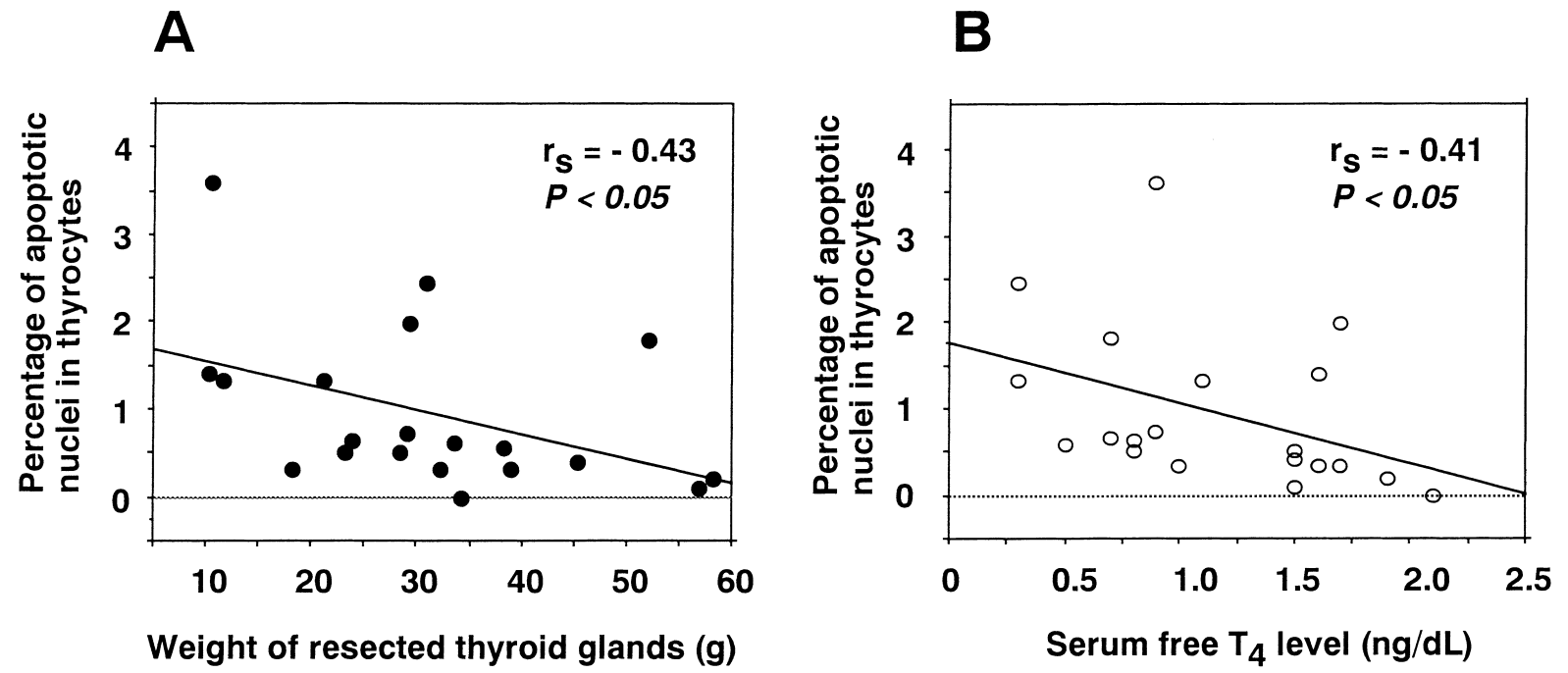

Fig. 3. Relationships between apoptosis of thyroid follicular cells and clinical parameters in Graves' disease (A, weight of the resected thyroid glands; $\mathrm{B}$, serum free $\mathrm{T}_{4}$ level).

Table 2. Relationships between Bak expression in thyrocytes and clinical parameters of Graves' disease.

\begin{tabular}{lccc}
\hline & \multicolumn{2}{c}{ Bak expression in thyrocytes } & \\
\cline { 2 - 3 } & Positive & Negative & $P$ value \\
\hline Apoptosis (\%) & $1.66 \pm 0.66$ & $0.73 \pm 0.89$ & $P<0.05$ \\
$\begin{array}{l}\text { Weight of the resected } \\
\text { thyroid glands }(\mathrm{g})\end{array}$ & $32.4 \pm 11.6$ & $30.9 \pm 15.3$ & $\mathrm{NS}$ \\
Free $\mathrm{T}_{3}(\mathrm{pg} / \mathrm{mL})$ & $3.9 \pm 2.1$ & $4.8 \pm 1.2$ & $\mathrm{NS}$ \\
Free $\mathrm{T}_{4}(\mathrm{ng} / \mathrm{dL})$ & $0.78 \pm 0.58$ & $1.28 \pm 0.48$ & $P=0.07$ \\
TRAb $(\%)$ & $48.1 \pm 27.2$ & $33.0 \pm 19.9$ & $\mathrm{NS}$ \\
\hline
\end{tabular}

Values are expressed as mean $\pm \mathrm{SD}$.

Apoptosis are assessed as percentages of apoptotic nuclei of thyrocytes. TRAb: anti-thyrotropin receptor antibody

NS: not significant

with GD. In autoimmune thyroid diseases, the increased apoptosis has been reported in Hashimoto's thyroiditis [8-14], while it has been controversial in GD $[8-11,18,19,22]$. In the present study we demonstrated apoptotic nuclei in thyroid follicular cells. The percentage of apoptotic follicular cells ranged from $0 \%$ to $3.6 \%$. It was smaller compared to Hashimoto's thyroiditis [8-13], and statistically not different from normal. Similar values were reported by Hammond et al. $(<1.0 \sim 3.5 \%)$ [11], whereas Kotani et al. [8] reported much higher values (7 14\%), and Okayasu et al. $\left(0 \sim 5 / 10^{5}\right)[10]$ and Tanimoto et al. $(0 \%)$ [9] reported smaller values. Recently Labat-Moleur et al. [24] reported that apoptosis was more often found in thyroid parenchyma showing epithelial hy- perplasia, cellular hypertrophy and little colloid, than that returning to regular shape lined by cuboidal or even flat cells and densely filled with colloid. Therefore, the discrepancies among the reports might be attributed to the differences in treatment for GD (antithyroid drugs or ${ }^{131}$ I therapy) or disease activity of GD. Furthermore, we demonstrated that the mean percentage of apoptotic follicular cells was negatively correlated with weight of the resected thyroid glands and with free $\mathrm{T}_{4}$ level. These results suggest that hyperplasia may be inversely related with apoptosis of thyrocytes, although the preoperative administration of iodine and anti-thyroid drugs might also affect the results. Vitale et al. [27] reported that iodide excess induces apoptosis in human thyroid cells through a p53-independent mechanism. The close relationship between apoptosis and goiter formation in rat model supports our observation in human [28]. Kawakami et al. [29] reported that GD immunoglobulins inhibited the Fas-mediated apoptosis in vitro. However, we could not show a correlation between apoptosis of thyrocytes and serum TRAb levels.

It is known that $\mathrm{Bcl}-2$ family proteins regulate apoptosis [2]. The ratio of the expression of death antagonists (Bcl-2, Bcl-XL) to death agonists (Bax, Bak) determines the survival or death of cells in physiological and pathological conditions [2]. The present study confirmed that normal thyroid follicular cells expressed Bcl-2 [9-11, 13] and Bak [30], suggesting that Bcl-2 and Bak expression in normal thyroid follicular cells 
may regulate apoptosis in the physiological state. There is no report on the expression of Bak in GD thyrocytes. The present study showed that Bak was expressed in 5 of 20 GD thyroid glands. Although there were no correlations between Bak expression in thyrocytes and free $T_{3}$, free $T_{4}$ or TRAb levels, the mean percentage of apoptotic thyrocytes was significantly greater in Bak-positive thyroid glands than in Bak-negative thyroid glands. However, there was no difference in the resected weight of thyroid glands between Bak-positive and Bak-negative groups. The failure of the relation of Bak expression with weight of the thyroid or free T4 levels may be due to the small number of patients or small percentage of apoptotic nuclei. Therefore, it remains unclear whether the down-regulation of Bak expression in GD contributes to the hyperplasia which is characteristic of GD. Future analysis on the regulation of the expression of Bcl-2 family proteins in thyrocytes may provide a new insight into the pathophysiology of GD.

With respect to the Bax expression in thyroid follicules, Labat-Moleur et al. [24] reported that Bax was localized as a paranuclear dot in both GD and normal thyrocytes and also expressed finely and diffusely during early apoptosis, while neither the previous reports $[3,4]$ nor the present study found Bax expression in normal thyrocytes. The discrepancies among the reports might be due to the differences in treatment for GD or disease activity and to the technical differences of tissue fixation and/or staining procedures including antibodies against Bax.

This is the first report on the expression of Bcl-2 family proteins in lymphoid follicles in GD. Bax and Bak, apoptotic agonists, were expressed in the germinal center of lymphoid follicles in all patients with GD, while Bcl-2, an apoptotic antagonist, was expressed in the mantle zone of lymphoid follicles. By contrast, apoptotic nuclei were more often found in the germinal center. These findinges were similar to findings on tonsils reported by Martinez-Valdez et al. [31]. They reported the expression of Bax, but not Bcl-2, in the germinal center of tonsils. Since germinal center formation is a dynamic process during the humoral immune response [32], the differential expression of Bcl-2 family proteins in lymphoid follicles may play a role in the humoral immune process in GD.

In conclusion, the expression of Bak in thyrocytes may be related to the sensitivity to apoptosis of GD thyrocytes. However, it remains unclear whether the down-regulation of Bak expression in GD reduces the apoptosis of thyrocytes and thus allows the hyperplasia of thyroid glands stimulated with TRAb associated with GD. It is also uncertain whether the differential expression of Bcl-2 family proteins in lymphoid follicles plays a role in the formation of the germinal center in GD. Further studies are indicated to clarify these issues.

\section{Acknowledgements}

We wish to thank Dr. Jack R. Wall, M.D., Ph.D. (The University of Melbourne, Victoria, Australia) for his valuable suggestions to this study.

\section{References}

1. Nagata S, Golstein P (1995) The Fas death factor. Science 267: 1449-1456.

2. Kroemer G (1997) The proto-oncogene Bcl-2 and its role in regulating apoptosis. Nature Med 3: 614-620.

3. Branet F, Brousset P, Krajewski S, Schlaifer D, Selves J, Reed JC, Caron P (1996) Expression of the cell death-inducing gene Bax in carcinoma developed from the follicular cells of the thyroid gland. J Clin Endocrinol Metab 81: 2726-2730.

4. Manetto V, Lorenzini R, Cordon-Cardo C, Krajewski S, Rosai J, Reed JC, Eusebi V (1997) Bcl-2 and Bax expression in thyroid tumours. An immunohistochemical and western blot analysis. Virchows Arch 430: 125130.

5. Gillardon F, Lenz C, Waschke KF, Krajewski S, Reed
JC, Zimmermann M, Kuschinsky W (1996) Altered expression of Bcl-2, Bcl-X, Bax, and c-Fos colocalizes with DNA fragmentation and ischemic cell damage following middle cerebral artery occlusion in rats. Brain Res Mol Brain Res 40: 254-260.

6. Basile DP, Liapis H, Hammerman MR (1997) Expression of bcl-2 and bax in regenerating rat renal tubules following ischemic injury. Am J Physiol 272: F640 647.

7. Kren BT, Trembley JH, Krajewski S, Behrens TW, Reed JC, Steer CJ (1996) Modulation of apoptosisassociated genes bcl-2, bcl-x, and bax during rat liver regeneration. Cell Growth Differ 7: 1633-1642.

8. Kotani T, Aratake Y, Hirai Y, Fukazawa Y, Sato H, Ohtaki S (1995) Apoptosis in thyroid tissue from 
patients with Hashimoto's thyroiditis. Autoimmunity 20: 231-236.

9. Tanimoto C, Hirakawa S, Kawasaki H, Hayakawa N, Ota Z (1995) Apoptosis in thyroid diseases: a histochemical study. Endocr J 42: 193-201.

10. Okayasu I, Saegusa M, Fujiwara M, Hara Y, Rose NR (1995) Enhanced cellular proliferative activity and cell death in chronic thyroiditis and thyroid papillary carcinoma. J Cancer Res Clin Oncol 121: 746-752.

11. Hammond LJ, Lowdell MW, Cerrano PG, Goode AW, Bottazzo GF, Mirakian R (1997) Analysis of apoptosis in relation to tissue destruction associated with Hashimoto's autoimmune thyroiditis. J Pathol 182: 138-144.

12. Giordano C, Stassi G, De Maria R, Todaro M, Richiusa P, Papoff G, Ruberti G, Bagnasco M, Testi R, Galluzzo A (1997) Potential involvement of Fas and its ligand in the pathogenesis of Hashimoto's thyroiditis. Science 275: 960-963.

13. Mitsiades N, Poulaki V, Kotoula V, Mastorakos G, Tseleni-Balafouta S, Koutras DA, Tsokos M (1998) Fas/Fas ligand up-regulation and Bcl-2 downregulation may be significant in the pathogenesis of Hashimoto's thyroiditis. J Clin Endocrinol Metab 83: 2199-2203.

14. Giordano C, Richiusa P, Bagnasco M, Pizzolanti G, Di Blasi F, Sbriglia MS, Mattina A, Pesce G, Montagna P, Capone F, Misiano G, Scorsone A, Pugliese A, Galluzzo A (2001) Differential regulation of Fas-mediated apoptosis in both thyrocyte and lymphocyte cellular compartments correlates with opposite phenotypic manifestations of autoimmune thyroid disease. Thyroid 11: 233-244.

15. Salmaso C, Bagnasco M, Pesce G, Montagna $\mathrm{P}$, Brizzolara R, Altrinetti V, Richiusa P, Galluzzo A, Giordano C (2002) Regulation of apoptosis in endocrine autoimmunity: insights from Hashimoto's thyroiditis and Graves' disease. Ann NY Acad Sci 966: 496-501.

16. Xerri L, Devilard E, Hassoun J, Mawas C, Birg F (1997) Fas ligand is not only expressed in immune privileged human organs but is also coexpressed with Fas in various epithelial tissues. J Clin Pathol: Mol Pathol 50: 87-91.

17. Stokes TA, Rymaszewski M, Arscott PL, Wang SH, Bretz JD, Bartron J, Baker JR Jr (1998) Constitutive expression of FasL in thyrocytes. Science 279: 2015 (www.sciencemag.org/cgi/content/full/279/5359/2015a)

18. Arscott PA, Baker JR Jr (1998) Apoptosis and thyroiditis. Clin Immunol Immunopathol 87: 207-217.

19. Hiromatsu Y, Hoshino T, Yagita H, Koga M, Sakisaka S, Honda J, Yang D, Kayagaki N, Okumura K, Nonaka K (1999) Functional Fas ligand expression in thyrocytes from patients with Graves' disease. J Clin Endocrinol Metab 84: 2896-2902.

20. Bretz JD, Baker JR Jr (2001) Apoptosis and autoimmune thyroid disease: following a TRAIL to thyroid destruction? Clin Endocrinol (Oxf) 55: 1-11.
21. Volpé, R (1989) Graves' disease. In: Braverman LE, Utiger RD (eds) Werner and Ingbar's The Thyroid, 6th ed. JB Lippincott Company, Philadelphia, 648-657.

22. Hiromatsu Y, Bednarczuk T, Soyejima E, Miyake I, Yang D, Fukazawa H, Nonaka K (1999) Increased serum soluble Fas in patients with Graves' disease. Thyroid 9: 341-345.

23. Kamijo K (2003) TSH-receptor antibody measurement in patients with various thyrotoxicosis and Hashimoto's thyroiditis: a comparison of two-step assays, coated plate ELISA using porcine TSH-receptor and coated tube radioassay using human recombinant TSH-receptor. Endocr J 50: 113-116.

24. Labat-Moleur F, Chabre O, Guillermet C, Chaffanjon P, Blumet-Rondeu F, Bauchet A, Franc B, Brambilla E, Bachelot I, Dumont JE, Negoescu A (1999) GravesBasedow disease goiter: a model of $\mathrm{Bax}-\mathrm{Bcl} 2$ regulated apoptosis. Thyroid 9: 483-493.

25. Hiromatsu Y, Kojima K, Ishisaka N, Tanaka K, Sato M, Nonaka K, Nishimura H, Nishida H (1993) Role of magnetic resonance imaging in thyroid-associated ophthalmopathy: its predictive value for therapeutic outcome of immunosuppressive therapy. Thyroid 2: 299-305.

26. Koga M, Hiromatsu Y, Jimi A, Inoue Y, Nonaka K (1998) Possible involvement of Fas-mediated apoptosis in eye muscle tissue from patients with thyroidassociated ophthalmopathy. Thyroid 4: 311-318.

27. Vitale M, Di Matola T, D’Ascoli F, Salzano S, Bogazzi F, Fenzi G, Martino E, Rossi G (2000) Iodide excess induces apoptosis in thyroid cells through a p53independent mechanism involving oxidative stress. Endocrinology 141: 598-605.

28. Tamura M, Kimura H, Koji K, Tominaga T, Ashizawa K, Kiriyama T, Yokoyama N, Yoshimura T, Eguchi K, Nakane PK, Nagataki S (1998) Role of apoptosis of thyrocytes in a rat model of goiter. A possible involvement of Fas system. J Clin Endocrinol Metab 139: 3646-3653.

29. Kawakami A, Eguchi E, Matsuoka N, Tsuboi M, Urayama S, Kawabe Y, Tahara K, Ishikawa N, Ito K, Nagataki S (1997) Modulation of Fas-mediated apoptosis of human thyroid epithelial cells by $\operatorname{IgG}$ from patients with Graves' disease (GD) and idiopathic myxoedema. Clin Exp Immunol 110: 434-439.

30. Brocker M, De-Buhr I, Papageorgiou G, Schatz H, Derwahl M (1996) Expression of apoptosis-related proteins in thyroid tumors and thyroid carcinoma cell lines. Exp Clin Endocrinol Diabetes 104 (Suppl. 4): 20-23.

31. Martinez-Valdez H, Guret C, De Bouteiller O, Fugier I, Banchereau J, Liu Y-J (1996) Human germinal center $\mathrm{B}$ cells express the apoptosis-inducing genes Fas, cmyc, P53, and Bax but not the survival gene bcl-2. $J$ Exp Med 183: 971-977.

32. Lindhout E, De Groot C (1995) Follicular dendritic cells and apoptosis: life and death in the germinal centre. Histochemical J 27: 167-183. 